\title{
The Influence of Distributive Justice and Procedural Justice in Job Satisfaction Through Perceived Organizational Supports (Case Study in GOJEK Surabaya)
}

\author{
Faizal Susilo Hadi ${ }^{* *} \&$ Kharis Septina Liftyawan ${ }^{2}$
}

\author{
${ }^{1}$ University of Surabaya, Surabaya, Indonesia \\ ${ }^{2}$ Airlangga University, Surabaya, Indonesia \\ *Corresponding author. Email: faizalsusilohadi@staff.ubaya.ac.id
}

\begin{abstract}
This research aims to investigate the effect of distributive justice and procedural justice on drivers' satisfaction. Through perceived organizational support, this research will examine the influence of distributive justice and procedural justice mutualism on drivers' satisfaction. This study was held in one of online transportation services in Surabaya namely Gojek with 200 respondents. This study applied quantitative method approach. The results show that perceived organizational support feels like mediating relations of distributive justice and procedural justice.

Keywords: distributive justice, procedural justice, job satisfaction, perceived organizational support.
\end{abstract}

\section{INTRODUCTION}

Industry 4.0 is marked by the fast-growing of technology and the internet. A lot of startup company born applying technology or digital concept. Besides, conventional companies are ready to digitalize their business to respond to what society needs today. Digital transformation increases their product and company value and provides services and products suitable to consumers nowadays. Furthermore, technology development can be used as a problem solving for consumer or known as society 5.0.

Gojek is one of many start-ups that succeeds in providing a solution for transportation through the mobile app. Gojek was first established in 2010 in Indonesia from call center service, and in 2015 Gojek expanded its business by launching a mobile app with a variety of products. Based on the research of Demographic Institution FEB Universitas Indonesia in 2019, Gojek has contributed Rp. 104,6 billion to the Indonesian econo- my. If we calculate using Product Domestic Bruto (PDB), Gojek has contributed around $1 \%$ of the 2019 national PDB.

Gojek's contribution to national PDB shows that it has an increased number of partners, even though sometimes its partners were protesting asking various demands. For example, a protest happened in Jakarta in 2016 because of lower fee rates to a half and no bonus for a driver (Nugroho 2016 instead of Kim 2017).

Protest frequently involves thousands of online drivers and consumers because of fluctuating fee rates and fraud in bonus calculations, so it harms some drivers (Nastiti 2017). Driver protest is a reaction to management's decision changes. Driver demands some fair fee rates and incentive scheme, no new driver recruitment, some transparency in suspended policy and free suspended drivers, easing individual license, a significant change in applicator management, transparency in license partnership, and eliminating priority driver programs. 
According to idntimes.com, online drivers protested, demanding a 20\% Gojek partnership tax reevaluated in 2020 .

The above events show job satisfaction that online drivers felt. Job satisfaction is frequently defined as a significant behavior in an organization because a delighted individual will increase his/her intrinsic motivation, organization commitment, and work outcome (Christen et al. 2006). Besides, satisfied workers will reduce the risk of stress at work, so job satisfaction is critical to discuss in this study.

Job satisfaction can be explained as a state of positive emotional vibes from a whole aspect in individuals' work or working experience. According to Leigh Jr. \& Woodman (1988), job satisfaction depends on worker's perceptions about management and the environment in work. Workers view a company has vast roles related to their job satisfaction. The conclusion is that the most significant factor that affects job satisfaction is within an organization or management. Therefore, we need to understand that management and company factors affect job satisfaction like supports and organization justice.

Jawahar \& Stone (2011) reveal that organizational justice has the most significant influence on job satisfaction. The individual that gives all their muscle, mind, and time (input) will, in return ask for promotion, salary, and profit (output) from a company. However, company's every management should balance it, which is perceived as organizational justice. When some individual output is lower than their input, they will gradually decrease their input, such as their job satisfaction behavior. Moreover, when workers believe their company resources are balanced and shared with all of the members, it will result in some positive vibes content around them.

Some of Gojek drivers in Surabaya felt dissatisfaction waves due to the decreasing of their fee rates issue. This issue is linked with rewards and then goes to one of the points of organizational justice: distributive justice. This distributive justice is proposed by Adams (1965) that states workers will conclude their perceptions about justice in their works and compare their input or ratio about their works with others. They call distributive justice workers concerned about how relatively managerial decisions about distributions and salaries, promotions, and others. Moreover, at the other point of transparency of suspended, transparency of partnership contracts and priority orders that need to be canceled reflects the other forms of organizational justice, namely procedural justice. Procedural justice is some fair perception in mechanism to give a better result. Greenberg (1990) adds that procedural justice is about equality to decide about distributing resources among workers.

Distributive justice and procedural justice significantly affect someone's trust and behavior about organization systems like performance and compensation systems (Jawahar 2007). Malatesta \& Byrne (1997) state that organizations commonly set a formal policy so that organization became the main factor for distributive justice and procedural justice. Studies about justice perception, including distributive justice and procedural justice, within outer in some level of the individual in organization refer to social exchange for a premise. Perceived organizational support is another form between individual social exchange and organization. Some actual research affirm distributive justice and procedural justice as a strong predictor from perceived organizational support (Ahmed et al. 2015, Biswas et al. 2013, Gillet et al. 2013; Jawahar \& Stone 2017, Kim 2017, Ohana 2012).

Eisenberger et al. (1986) define some workers' perceptions about an organizational concern or support resulting from trading between workers and organizations. Workers perceive organizational support as to how far organizations genuinely respect and care about their welfare. Organization systems and policies are functional elements of support to their workers. Because of it, any form of justice in a policy and systems will affect worker's perception of organizational support (Jawahar \& Stone 2017). Organizational 
support is recognition given by an organization concerning someone's achievement. Some measurements about their objective and satisfaction about their career are standard measurements about objective achievement (Hall \& Chandler 2005).

\subsection{Perceived organizational support}

Social Exchange Theory and Organizational Support Theory believe that how far organizations rate their contribution and care about workers' achievement will be a catalyst to their attitude, behavior, and productivity (Rhoades \& Eisenberger 2002). The mutualistic relationship between the organization and their support from one of (organization or workers) makes the others pay to bring good vibes to others. Mutualistic relationship between organizations and workers is supported by organizational support theory, which presumes in global believes about how far organization appreciates workers contribution and cares about them. And also believes as a guarantee if an organization will always support them when they are in a stressful situation of making their productivity effective (Eisenberger et al. 1986)

Rhoades \& Eisenberger (2002) show three commonly shaped organizations that consider goods and could elevate perceived organizational support. They are justice, support from supervisor, and also reward and working condition. Justice factors are used to distribute some resources in an organization. Repeated justice that makes decisions about distribution resources will strongly influence perceived organizational support shown in cares about workers welfare. Rhoades \& Eisenberger (2002) also reveal that organizational support is the most significant consequence of fair treatment in working conditions.

Availability support signifies that an organization appreciates contribution and cares about its worker's welfare. Workers that feel supported by the organization will be satisfied with their careers (Karatepe 2013). Satisfaction is one of their positive vibes, attitudes, and behaviors because organizations support them (Bilgin \& Demire 2012, Riggle et al. 2009).

\subsection{Distributive justice}

Social Adams (1965) defines the distributive justice concept as a condition when workers feel the justice at their works compared to their effort ratio with another coworker. Niehoff \& Moorman (1993) say that distributive justice is how fair they share their wages. According to Colquitt (2001), distributive justice is linked with the justice of organization sources such as salaries and profits. Most workers presume that rewards shares are fair when they meet their requirements such as justice, equality, and worker's needs.

Schiminke et al. (1997) stipulate that distributive conclusion is when individual perception about justice and distribution that they earn will affect their attitudes and behavior. Distributive justice is also an aspect of valuation about allocation sources to all workers and everyone involved-moreover, interpretation of consideration about workers who receive shares that they earned. In a specific way, the principle of distributive justice is not going along with a situation and goals that the organization needs. When comparing gaps and equality, it needs to be done carefully, considering individual characteristics are complex that value distributive justice goals are equality with organization visions.

\subsection{Procedural justice}

Leventhal (1980) defines procedural justice as an individual that allocation procedure fulfills specific criteria that are considered fair and appropriate. This concept is focused on an individual cognitive map from a predating reward and an evaluation event. According to Niehoff \& Moorman (1993), procedural justice is a perception influenced by how far suitable methods make allocation decisions that workers felt and fair guidance. Skarlicki \& Folger (1997) identify procedural justice known as a formal company pro- 
cedural justice. Furthermore, Badawi (2012) says that normative principles form procedural justice that workers felt. That principle is supposed to be like a consistent procedure about bargain reward, management consistency, avoid some individual interests in the distribution process, time management, methods improvement, and representation of rules and ethics.

\subsection{The relationship between distributive justice and perceived organizational support}

Distributive justice is used to predict job satisfaction through compensation and benefits, and working ethics included in working satisfaction (Cohen-Charash \& Spector 2001, Colquitt et al. 2001). Workers that assume rewards and resources distribution that allocated fair and equally consider support from organization, at that time workers will repay with cognitive, physics, and emotional in their working condition. According to Rhoades \& Eisenberger (2002), perceived organizational supports are most consequent significant from fair treatment in their working condition. Otherwise, organizational support could be some crucial results from fair practice distribution.

H1: Distributive justice is related positively to perceived organizational support.

\subsection{The relationship between procedural justice and perceived organizational support}

Justice policy and practical managerial, especially human resources established sources of information about worker's perception of procedural justice (Kuvaas 2008). Workers feel some organization decisions and other processes that not against their sides and discriminated are motivated to obey demands and legal aspects from the organization (Bies 2005). Procedural justice predicts any attitude and behavior workers on perceived organizational support (Rhoades \& Eisenberger 2002; Riggle et al., 2009). Workers perception about the justice of de- cisions also making some process that being done creates some trust that organization cares about their welfare (Moorman et al. 1998).

$\mathrm{H} 2$ : Procedural justice is related positively to perceived organizational support.

\subsection{The relationship between perceived organizational support and job satisfaction}

When workers think that their management does not support them, they look at their jobs that they think are not pleased them and dissatisfaction at work (Susskind et al. 2000). This perception shows that organizations do not care, respect, and agreements to work and shows that organizations do not give them adequate help when they need to make their job more effective (Rhoades \& Eisenberger 2002). Empirically, Erdogan et al. (2004) also Jawahar \& Stone (2017) show a significant positive relationship between perceived organizational support and job satisfaction.

H3: Perceived organizational support is related positively to job satisfaction.

\subsection{The relationship between distributive justice and job satisfaction through perceived organizational support}

Social exchange theory is integrated to submit a model to investigate the mediation effect of perceived organizational support on the relationship between distributive justice and job satisfaction. Perceived organizational support refers to individual faith about how much organization appreciates their efforts and contribution also linked with workers welfare (Eisenberger et al. 1986). The fact that perceived organizational support is frequently tested and proven to be a mediation variable between organizational justice and job satisfaction (Kim 2017, Lavelle et al. 2007). Connection and relation between distributive justice and perceived organizational support, also perceived organizational support with job satisfaction, many studies that prove positive relation (Biswas et al. 
2013, Gillet et al. 2013. Kim 2017, Ohana 2012)

H4: Perceived organizational support will mediate the relationship between distributive justice and job satisfaction.

\subsection{The relationship between procedural justice and job satisfaction through perceived organizational suppport}

This research also sees the mediation role of perceived organizational support because it is a significant mechanism that will explain how organizational factors pointed at many positive results (Ahmed \& Nawaz 2015). This research shows that perceived organizational support pointed at positive results at works, including job satisfaction (Rhoades \& Eisenberger 2002). (Fu \& Lihua 2012) explain that procedural justice will significantly impact perceived organizational support with care attitude to workers welfare. (Cropanzano, Bowen \& Gilliland, 2007) say procedural justice will improve workers' confidence in the organization, increasing perceived organizational support. Consistent with this point of view, some researchers (Gillet et al. 2013, Rhoades et al. 2001) give some empirical support mediation role from perceived organizational support relationship between procedural justice and job satisfaction.

H5: Perceived organizational support will mediate the relationship between procedural justice and job satisfaction

\section{RESEARCH METHODS}

This research was held on Gojek drivers around Surabaya city. This research used quantitative method. Accidental sampling was applied in this collecting method with certain criteria. Around 200 respondents were collected for data sampling. Respondents also commented on characteristic demography like age, sex, years of service, and education. Partial Least Squares analysis (PLS) is a tool used in this research because it can calculate all coefficient lanes at the same time so it can analyze all direct and indirect relations.

Measurement variables of distributive justice, procedural justice, job satisfaction, and perceived organizational support use a 5-point Liker scale ranging from 5 (very agree) to 1 (very disagree).

Distributive justice variable is measured from Colquitt (2001) measurement of 4-item and has Cronbach's alpha value of 0.905 . Procedural justice variable is measured from Leventhal (1980) measurement of 7-item and has Cronbach's alpha value of 0.924 . Job satisfaction variable is measured from Spector (1985) measurement of 22-item and has Cronbach's alpha value of 0.967. And the last one is perceived organizational support variable is measured from Farmer \& Fedor (1999) measurement of 7-item and has Cronbach's alpha value of 0.918 .

Table 1. Hypothesis testing.

\begin{tabular}{lcc}
\hline $\begin{array}{l}\text { Correlation between } \\
\text { variable }\end{array}$ & $\begin{array}{c}\mathrm{t} \\
\text { statistics }\end{array}$ & $\begin{array}{c}\text { original } \\
\text { sample }\end{array}$ \\
\hline $\begin{array}{l}\text { Distributive justice } \\
\rightarrow \text { perceived }\end{array}$ & & \\
$\quad$ organizational support & 5.091 & 0.305 \\
$\begin{array}{l}\text { Procedural justice } \\
\rightarrow \text { perceived }\end{array}$ & & \\
$\quad$ organizational support & 6.159 & 0.376 \\
$\begin{array}{l}\text { Perceived organizational } \\
\text { support } \rightarrow \text { job satisfaction }\end{array}$ & 7.030 & 0.300 \\
$\begin{array}{l}\text { Distributive justice } \rightarrow \\
\text { perceived organizational } \\
\text { support } \rightarrow \text { job satisfaction }\end{array}$ & 3.772 & - \\
$\begin{array}{l}\text { Procedural justice } \rightarrow \\
\text { Perceived organizational } \\
\text { support } \rightarrow \text { job satisfaction }\end{array}$ & 4.948 & - \\
\hline
\end{tabular}

\section{RESULTS AND DISCUSSIONS}

Statistical test results show that the value of $\mathrm{R} 2$ in variable job satisfaction is 0.812 . It signifies that around $81.2 \%$ works content value that could be explained by distributive justice, procedural justice, and perceived organizational support. In contrast, the rest of $18.8 \%$ is explained by the outside analytics model of the variable. Furthermore, the R2 
value of the perceived organizational support is 0.768 signifying around $76.8 \%$ variable value organizational support explained by distributive justice and procedural justice. The rest of $23.2 \%$ is explained by variables outside of the analysis model.

Based on the statistical test model in Table 1 , the $\mathrm{t}$-statistic value affected distributive justice to perceived organizational support around 5.091 (>1.96) and the value of the original sample around 0.354 (positive) so that $\mathrm{H} 1$ is accepted. It signifies higher distributive justice felt by Gojek driver, so the perceived organizational support will increase. This research is supported by Rhoades \& Eisenberger's (2002) research. The second hypothesis test result shows that value of statistic effect to procedural justice to organizational support that felt around 6.159 (>1.96) and value of original sample around 0.376 (positive) so that $\mathrm{H} 2$ is accepted. It signifies higher procedural justice felt by Gojek driver, so the organizational supports that felt will increase. This research is supported by Rigel et al. (2009) research. The third hypothesis test result shows that the value t-statistic effect to perceived organizational support to job satisfaction around $7.300(>1.96)$ and the value of the original sample around 0.3000 (positive) so that $\mathrm{H} 3$ is accepted. It signifies higher perceived organizational support by Gojek driver, so job satisfaction will increase. This research is supported by Jawahar \& Stone's (2017) research. The fourth hypothesis says that the value of distributive justice influences job satisfaction through perceived organizational support around $3.772(>1.96)$, so that means $\mathrm{H} 4$ is accepted. Finally, the fifth hypothesis says that procedural justice influences job satisfaction through perceived organizational support around 4.948 (>1.96), which means H5 is accepted.

Masterson et al. (2000) explain that worker's sensitivity about distributive justice could predict how far the workers consider their company respects their contributions; in another way, workers feel their organizational support. There is some mutualistic relationship happens between workers and their company. When a company can fairly share in the distribution of wages, job desk, and promotion, a company will perceive how care they are to workers welfare. How high their distributive justice that Gojek drivers felt, and the variation of valuable organizational support they felt is high. Gojek drivers feel that distributive existence feels that their company is fair on their sides because they feel they support them too.

This research also gives some point of view about the existence of procedural justice that Gojek drivers feel have a role in increasing their perception about how their company cares about their welfare. It is recommended to increase further positive perception about company actions that need to be done to impact how far their company supports them positively.

Workers that are treated relatively have better work satisfaction in their mind. Support that company gives to them can produce some positive responses to them to increase their works welfare. It is expanded by Eisenberger et al. (1986), who say that if workers get better support from the companies, they will show a better positive attitude to the companies. Conclusion about that statement is that company support can be felt when workers believe that the company cares about them and fully support them to develop themselves.

The rise of organizational support that workers felt by Gojek drivers have a role in increasing job satisfaction of Gojek drivers. Furthermore, it is recommended because the impact of organizational support will push Gojek drivers to be more excited and more enjoyed and also makes them believed to express their interests and expand their visions along with their organization. Visions and targets achievement that organization specified is a result of how well an organization treated their workers. Good treatment of an organization to their workers will also create a good commitment that shapes worker's attitude continuity. Otherwise, when a company satisfies their worker's needs of socioemotional like acknowledgment and rewards, it is confirmed that workers will love 
their company more and never think about resignation, as long as they feel comfortable and satisfied.

The mediation influence that was filed in this research was successful and gave a significant result. But not higher than a significant direct result. This also indicates that variable of organizational support that felt only mediated partial relation between distributive justice and procedural justice to workers welfare

\section{CONCLUSION}

Social exchange theory and organizational support theory explain that organizational support that felt became a catalyst of positive results about attitude, behavior, and performance. This study shows that distributive justice and procedural justice increase workers' job satisfaction through perceived organizational support as a mediation variable. Even that organizational support that felt could be a significant factor of mediator that gives more significant value to a relationship that happened; the reality is this variable is not more significant than direct relation that happened. This indicates that wages schemes and processes that preceded it have been enough to make Gojek drivers satisfied-no need for further explanation about mediate relation of mediation that impacts job satisfaction.

\section{REFERENCES}

Adams, J. S. 1965. Inequity in Social Exchange. Advances in Experimental Social Psychology 2(C): 267-299. 2601(08)60108-2.

Ahmed, I. \& Nawaz, M.M. 2015. Antecedents and outcomes of perceived organizational support: A literature survey approach. Journal of Management Development 34(7): 867-880. https://doi.org/10.1108/JMD-09-2013-0115

Ahmed, I. Nawaz, M.M. Ali, G. \& Islam, T. 2015. Perceived organizational support and its outcomes. Management Research Review 38(6): 627-639. https://doi.org/10.1108/MRR-09-20130220 .
Badawi. 2012. Peran Emosi Memediasi Keadilan Distributif, Prosedural Dan Interaksional Terhadap Kepuasan Pemulihan Layanan. Jurnal Manajemen Dan Akuntansi 1(1): 13-26.

Bies, R.J. 2005. Are Procedural Justice and Interactional Justice Conceptually Distinct? In Handbook of organizational justice. Mahwah: Lawrence Erlbaum Associates Publishers.

Bilgin, N. \& Demirer, H. 2012. The Examination of the Relationship Among Organizational Support, Affective Commitment and Job Satisfaction of Hotel Employees. Procedia-Social and Behavioral Sciences 51: 470-473. https://doi.org/10.1016/j.sbspro.2012.08.191.

Biswas, S. Varma, A. \& Ramaswami, A. 2013. Linking distributive and procedural justice to employee engagement through social exchange: a field study in India. The International Journal of $\mathrm{Hu}$ man Resource Management 24(8): 1570-1587. https://doi.org/10.1080/09585192.2012.725072.

Christen, M. Iyer, G. \& Soberman, D. 2006. Job satisfaction, job performance, and effort: A reexamination using agency theory. Journal of Marketing 70(1): 137-150. https://doi.org/10.1509/jmkg.2006.70.1.137.

Cohen-Charash, Y. \& Spector, P.E. 2001. The role of justice in organizations: A meta-analysis. Organizational Behavior and Human Decision Processes 86(2): 278-321. https://doi.org/10.1006/obhd.2001.2958.

Colquitt, J.A. 2001. On the dimensionality of organizational justice: A construct validation of a measure. Journal of Applied Psychology 86(3): 386400. https://doi.org/10.1037/0021-9010.86.3.386

Colquitt, J.A. Wesson, M.J. Porter, C.O.L.H. Conlon, D.E. \& Ng, K.Y. 2001Justice at the millennium: A meta-analytic review of 25 years of organizational justice research. Journal of Applied Psychology 86(3): 425-445. https://doi.org/10.1037/0021-9010.86.3.425.

Cropanzano, R. Bowen, D.E. \& Gilliland, S.W. 2007. The Management of Organizational Justice. Academy of Management Perspectives 21(4): 34 48. https://doi.org/10.5465/amp.2007.27895338.

Eisenberger, R. Huntington, R. Hutchison, S. \& Sowa, D. 1986. Perceived Organizational Support. Journal of Applied Psychology 71(3): 500 507. https://doi.org/10.1037/0021-9010.71.3.500.

Erdogan, B. Kraimer, M.L. \& Liden, R.C. 2004. Work value congruence and intrinsic career success: The compensatory roles of leader-member exchange and perceived organizational support. Personnel Psychology 57(2): 305-332. https://doi.org/10.1111/j.17446570.2004.tb02493.

Farmer, S.M. \& Fedor, D.B. 1999. Volunteer participation and withdrawal. Nonprofit Management and Leadership 9(4): 349-368. https://doi.org/10.1002/nml.9402. 
Fu, Y. \& Lihua, Z. 2012. Organizational justice and perceived organizational support: The moderating role of conscientiousness in China. Nankai Business Review International 3(2): 45-166. https://doi.org/10.1108/20408741211244398

Gillet, N. Colombat, P. Michinov, E. Pronost, A.M. \& Fouquereau, E. 2013. Procedural justice, supervisor autonomy support, work satisfaction, organizational identification, and job performance: The mediating role of need satisfaction and perceived organizational support. Journal of Advanced Nursing 69(11): 2560-2571. https://doi.org/10.1111/jan.12144.

Greenberg, J. 1990. Organizational Justice: Yesterday, Today, and Tomorrow. Journal of Management 16(2), 399-432. https://doi.org/10.1177/014920639001600208.

Hall, D.T. \& Chandler, D.E. 2005. Psychological success: When the career is a calling. Journal of Organizational Behavior 26(2): 155-176. https://doi.org/10.1002/job.301

Jawahar, I. M. 2007. The influence of perceptions of fairness on performance appraisal reactions. Journal of Labor Research 28(4): 735-744. https://doi.org/10.1007/s12122-007-9014-1.

Jawahar, I. M. \& Stone, T. H. 2011. Fairness perceptions and satisfaction with components of pay satisfaction. Journal of Managerial Psychology 26(4): 297-312. https://doi.org/10.1108/02683941111124836.

Jawahar, I.M. \& Stone, T. H. 2017. Do career satisfaction and support mediate the effects of justice on organizational citizenship behaviour and counterproductive work behaviour? Canadian Journal of Administrative Sciences 34(3): 215-228. https://doi.org/10.1002/cjas.1350

Karatepe, O.M. 2013. The effects of work overload and work-family conflict on job embeddedness and job performance. https://doi.org/10.1108/09596111311322952

Kim, S. 2017. Perceived organizational support as a mediator between distributive justice and sports referees' job satisfaction and career commitment. Annals of Leisure Research 20(2): 169-187. https://doi.org/10.1080/11745398.2016.1147363.

Kuvaas, B. 2008. An Exploration of How the Employee? Organization Relationship Affects the Linkage Between Perception of Developmental Human Resource Practices and Employee Outcomes. Journal of Management Studies 45(1): 70605080020007-??? https://doi.org/10.1111/j.1467-6486.2007.00710.x

Lavelle, J.J. Rupp, D.E. \& Brockner, J. (2007). Taking a multifoci approach to the study of justice, social exchange, and citizenship behavior: The target similarity model. Journal of Management, 33(6), $841-866$. https://doi.org/10.1177/0149206307307635

Leigh, J. H. Jr. \& Woodman, R.W. 1988. Effects of Perceived Organizational Factors on Role Stress-
Job Attitude Relationships. Journal of Management 14(1): 41-58. https://doi.org/doi/10.1177/014920638801400105

Leventhal, G.S. 1980. What Should Be Done with Equity Theory? In Social Exchange. https://doi.org/10.1007/978-1-4613-3087-5_2.

Malatesta, R.M. \& Byrne, Z. 1997. The Impact of Formal and Interactional Justice on Organizational Outcomes. The Annual Meeting of The Society for Industrial and Organizational Psychology.

Masterson, S.S. Lewis, K. Goldman, B.M. \& Taylor, M.S. 2000. Integrating Justice and Social Exchange: The Differing Effects of Fair Procedures and Treatment on Work Relationships. Academy of Management Journal 43(4): 738-748. https://doi.org/10.5465/1556364.

Moorman, R.H. Blakely, G.L. \& Niehoff, B.P. 1998. Does perceived organizational support mediate the relationship between procedural justice and organizational citizenship behavior? Academy of Management Journal 41(3): 351-357. https://doi.org/10.2307/256913.

Nastiti, A.D. 2017. Worker Unrest and Contentious Labor Practice of Ride-Hailing. Arryman Symposium.

Niehoff, B.P. \& Moorman, R.H. 1993. Justice as a Mediator of the Relationship Between Methods of Monitoring and Organizational Citizenship Behavior. Academy of Management Journal 36(3): 527-556. https://doi.org/10.5465/256591.

Ohana, M. 2012. Perceived Organisational Support As Mediator Of Distributive Justice And Job Satisfaction: The Moderating Role Of Group Commitment. Journal of Applied Business Research 28(5):

1063. https://doi.org/10.19030/jabr.v28i5.7246.

Rhoades, L. \& Eisenberger, R. 2002. Perceived organizational support: A review of the literature. Journal of Applied Psychology 87(4): 698-714. https://doi.org/10.1037/0021-9010.87.4.698.

Rhoades, L. Eisenberger, R. \& Armeli, S. 2001. Affective commitment to the organization: The contribution of perceived organizational support. Journal of Applied Psychology 86(5): 825-836. https://doi.org/10.1037/0021-9010.86.5.825.

Riggle, R.J. Edmondson, D.R. \& Hansen, J.D. 2009. A meta-analysis of the relationship between perceived organizational support and job outcomes: 20 years of research. Journal of Business Research 62(10): 1027-1030. https://doi.org/10.1016/j.jbusres.2008.05.003.

Schminke, M. Ambrose, M.L. \& Noel, T.W. 1997. The effect of ethical frameworks on perceptions of organizational justice. Academy of Management Journal 40(5): 1190-1207. https://doi.org/10.2307/256932.

Skarlicki, D.P. \& Folger, R. 1997. Retaliation in the workplace: The roles of distributive, procedural, and interactional justice. Journal of Applied Psy- 

chology
82(3):
$434-443$.

https://doi.org/10.1037/0021-9010.82.3.434.

Spector, P.E. 1985. Measurement of human service staff satisfaction: Development of the Job Satisfaction Survey. American Journal of Community
Psychology
13(6):
693-713.

https://doi.org/10.1007/BF00929796.

Susskind, A.M. Borchgrevink, C.P. Kacmar, K.M. \& Brymer, R.A. 2000. Customer service employees' behavioral intentions and attitudes: An examination of construct validity and a path model. International Journal of Hospitality Management 19(1): 53-77. https://doi.org/10.1016/S02784319(99)00030-4. 